\title{
MIGRATION AND DEVELOPMENT ORGANIZATIONS: THE DIVERSIFICATION OF CIVIL SOCIETY AND PUBLIC POLICIES IN SPAIN
}

\author{
Joan LACOMBA', Mourad ABOUSSI"
}

COBISS 1.01

\section{ABSTRACT \\ Migration and Development Organizations: The Diversification of Civil Society in Spain}

The conjunction between the last few decades' public policy changes and the impact of the growth of immigration in Spain has had a transformative effect on the third sector. The government trend toward outsourcing the management of international development cooperation programs and social services has shifted much of the state's responsibility onto the shoulders of civil society organizations. The context has subjected them to tensions and changes in the way they take action and the way they are organized. This article, based on two research projects, explores the adaptations and new forms of relationships among the main actors involved in the field of migration and development.

KEY WORDS: Spain, civil society, immigration, NGDO, associations, public policies

\section{IZVLEČEK}

Migracijske in razvojne organizacije: Diverzifikacija civilne družbe in javnih politik v Španiji

Povezava med spremembami javne politike $v$ zadnjih desetletjih in vplivom naraščajočega števila priseljencev $v$ Španiji je imela transformativen učinek na tretji sektor. Vladni trend zunanjega najemanja vodstvenih kadrov mednarodnih razvojnih kooperativnih programov in socialnih služb je dobršen del odgovornosti države prevalil na ramena civilnodružbenih organizacij. Novi kontekst je prinesel napetosti in spremembe $v$ načinu delovanja in organiziranja. Članek, ki temelji na dveh raziskovalnih projektih, obravnava prilagoditve in spremembe $v$ odnosih med glavnimi protagonisti na področju migracij in razvoja.

KLJUČNE BESEDE: Španija, civilna družba, priseljenci, nevladne razvojne organizacije, združenja, javne politike

PhDin Sociology, Professor of Social Work, Department of Social Work, Faculty of Social Sciences, University of Valencia, Campus Tarongers, Avda. Tarongers 4-B, 46022-Valencia, Spain; joan.lacomba@uv.es

\| PhD in Social Sciences, Professor of Social Work, Department of Social Work and Social Services, Faculty of Social Work, University of Granada, Spain, C/Rector López Argüeta, Edificio San Jerónimo s/n, 18071-Granada, Spain; maboussi@ugr.es — Funding: This work is the result of an R\&D project supported by the Spanish Ministry of Science, Innovation and Universities (CSO2015-66181-R). 


\section{INTRODUCTION}

The relationship between the state and the third sector (a more-limited term for referring to the nebula of organizations that make up civil society) is already a classic topic of study in the social sciences. Much international scientific production studies the third sector, looking especially into the sector's role as a provider of work that complements or substitutes the work of the state (Salamon 1994; Salamon 2003). Such research is concerned fundamentally with analyzing the framework in which the state/third sector relationship takes place and the degree to which it is developed. Spain has quite the history of specialized literature about the third sector and the state, too, following the path blazed by scholars abroad and endeavoring to track the rise of nonprofit entities in multiple realms of Spanish society, such as social action (Rodríguez Cabrero 2015; Renes Ayala 2018) and more specifically development cooperation (Serrano Oñate 2019).

As far back as the early 1990s, Salamon (1994) spoke of the worldwide rise of the third sector in terms of a "global associational revolution," one that had even caused a change in relations between the state and citizens. Salamon and his companions understood the third sector, or nonprofit sector, as the set of "all entities that are formal organizations having an institutionalized character; constitutionally independent of the state and self-governing; non-profit-distribution; and involving some degree of volunteerism" (Kendall, Almond 1999: 234). Over the years the third sector's presence has become a steadfast major component of the institutional landscape of the more-developed countries, and in that of a good many of the developing countries, too. The Spanish third sector, with its own country-specific features, has also acquired considerable clout; the magnitude of its importance has been reflected in a number of reports (Fundación Lealtad 2015; Plataforma de ONG de Acción Social and Plataforma del Tercer Sector 2015; Price Waterhouse Coopers 2018).

By contrast, both internationally and domestically, we still have large gaps in terms of analysis: analysis of the organizations that take part in the third sector and above all analysis of the changes that have happened within organizations as they have grown more prominent and new organizations have joined the field (the classic notion of the third sector ignores or limits the visibility of organizations from the field of migration or development). ${ }^{1}$ As increasing numbers of ever-more-vibrant organizations related with the field of migration have come into being, creating an organizational effervescence, some authors like Fox (2005) and others like Theodore and Martin (2007) have coined the term "migrant civil society" to refer to this part of civil society, the part where immigrants themselves are the protagonists. Fox holds that the migrant civil society settled in the United States has two main components: organizations based on migrants themselves and local civil society

1 For example, Salamon's classic classification (1994) includes no references to development entities or entities made up of migrants. 
organizations that have been transformed by the participation and leadership of migrants (Fox 2005).

One of the most interesting changes to happen over the last two decades in Spain has been the appearance of new actors on the civil society scene (immigrants' associations) and the reaccommodation of other actors that are not much older than the newcomers (NGDOs). In this new context, a considerable number of NGDOs and immigrants' associations have been working together in projects and activities, both in Spain and in migrants' countries of origin. Their joint work and its contribution to the construction of a more solid, diverse civil society are often unknown. Some Spanish NGDOs well experienced in development cooperation have mentored, supported or strengthened immigrants' associations in their activities. Immigrants' associations, too, some of which have themselves become NGDOs, have earned a major role in the realm of development cooperation, where they demand their own space as emerging actors and even provide support for smaller or newer associations. At the same time, many people of immigrant origin form an active part of Spanish NGDOs, where they have become integrated into the NGDO leadership, found jobs as technicians or volunteer. These new realities associated with the influx of immigration have brought significant elements of change to the realm of Spanish civil society involved in national and international development. The entry of immigrants' associations in the third sector has added an element of great heterogeneity to the mix.

We may say that, just as society has become more culturally diverse with the arrival of immigration, civil society has become more organizationally diverse, incorporating new entities and forms of organization. Feldman et al. (2005) affirm that civil society's new organizations act like a microcosm of the broader changes due to immigration and ethnic diversification. However, a good part of these transformations have not been thoroughly studied.

Our objective in this article is explore some of the changes in the realm of migration and development organizations. We begin with the hypothesis that the transformations affecting relationships between the state and civil society and the impact of certain public policies (the political opportunity structure) have been distinctly mirrored in the rearrangement of the third sector, and that at the same time the incorporation of immigration in Spain has acted as an added factor in this process of change, making the organizational field more complex and diverse.

With these as our premises, in the first section we describe the methodological framework surrounding the two research projects on which the article is based. In the second section we briefly explore the problem of the relationship between the third sector (civil society) and the state and then zoom in on how development and immigration organizations fit into the Spanish third sector, taking account of the sector's complexity and the diversity of its component entities. The third section analyzes the role of and difficulties in the link between NGDOs and immigrants' associations and pinpoints the most common forms of relationships between organizations. The fourth section focuses on how public policy on co-development affects 
the remodeling of the relationships between organizations, in the context of greater organization recognition and transnationalization. Lastly, we state a series of conclusions that point to political changes that question the role organizations in the field of migration and development have played of late.

\section{METHODOLOGY AND SOURCES}

The main sources of information for this article are a study of immigrants' associations and a study of NGDOs in Spain, both financed under the Spanish ministerial call for RDI project proposals. The first study was carried out from 2012 to 2014, with the objective of gaining an overview of immigrants' associations and their role in development in immigrants' countries of origin. The study's main instrument was a survey of 206 associations of migrants from eight countries (Algeria, Bulgaria, Colombia, Ecuador, Mali, Morocco, Romania and Senegal) from among the 852 associations identified after a sweep of official registries and unofficial registries (24\% of the associations identified). The survey was implemented in early 2013, both on line and by telephone. The questionnaire gathered general information on the associations, their activities in Spain, their activities in their country of origin, those of their activities in their country of origin that are directly connected with development and those of their activities in their country of origin that are defined specifically as co-development. The survey was subsequently complemented with 50 in-depth interviews of leaders of the associations that reported having conducted development activities in their countries of origin.

After this study, we embarked on a second research project to learn more about the role of NGDOs as strategic actors in the field of development and their relationships with immigrants' associations in that space. In this second study, run from 2016 to 2018, we conducted a fresh survey, this time targeting NGDOs. The survey universe was made up of the 2,072 NGDOs registered with the Agencia Española de Cooperación Internacional al Desarrollo (Spanish International Development Cooperation Agency, or AECID) on October 12, 2016. We administered the survey to 332 NGDOs (16\% of the universe), based on a sample stratified territorially by autonomous communities (the main administrative and political subdivisions of Spain); this is equivalent to a significant sample with an estimated error of $4.9 \%$ and a confidence level of $95 \%$. The survey's field work was done in two phases, each with its own strategy. Phase one was an online survey in which a questionnaire was sent to the entire universe of NGDOs registered with the AECID that had an e-mail address. The survey, using the Lime Survey application, was implemented from February to March 2017, and 108 replies were obtained. Phase two was a telephone survey, in which calls were made randomly to NGDOs registered with the AECID that had a telephone number and had not answered on line, until the territorial sample was complete. The survey was implemented from April to May 2017, obtaining a total of 
224 replies. The NGDOs that reported having had collaborative relationships with immigrants' associations were asked for supplementary information about their project experience, until 46 relationship reports had been filled out.

The information gleaned from the surveys and interviews done in the two studies gave us a general map of the entities linked to the realms of migration and development in Spain, plus a more precise knowledge of the role of immigrants' associations and NGDOs, especially as regards the degree and the type of relationships between the two types of organizations.

\section{DEVELOPMENT AND IMMIGRATION ORGANIZATIONS AND THE THIRD SECTOR IN SPAIN}

The third sector has taken on an increasingly relevant role in the management of issues affecting the immigrant population: in Canada as reported by Richmond and Shields (2005), Landolt, Goldring and Bernhard (2009), Paré and Maloumby-Baka (2015); in the United States (Bloemraad 2005; Theodore, Martin 2007); and in Europe (Revilla Blanco 2002; Feldman et al. 2005; Cullen 2009; Saglie, Sivesind 2018). There the third sector has been burdened with providing services in exchange for access to public moneys and one-off participation in political deliberations, within a climate where organizations are professionalized, bureaucratized and deradicalized.

The third sector, now the hard core of Spanish civil society, has become a respectable force in Spain and shares many similarities with the third sector in similar countries (Ruiz Olabuénaga et al. 1999), but it also presents a number of special features. One of them is the diversity of the third sector itself. Traditionally a line has been drawn dividing social action NGOs working with the population in Spain from development NGOs (NGDOs) working with similar principles, i.e., fighting against exclusion and poverty, but in the realm of international cooperation (Revilla Blanco 2015).

The evolution of and changes in the third sector and immigration in Spain coincide largely with what has happened in developed societies like ours on the whole over the last three decades (Garkisch, Heidingsfelder, Beckmann 2017). The organizations of civil society have shouldered a good share of the weight of managing services stemming from certain public policies. In effect, the various immigrant population care programs in Spain are primarily run by non-profit social entities. It is NGOs that take on responsibility for managing programs paid for by public funds, which are secured through a range of subsidies (Moreno, Bruquetas 2011).

The reasons are in reality much deeper, however, and they have to do with the Spanish social model and the crisis of the unconsolidated welfare state (Cachón, Laparra 2009). Shortcomings such as this in the heart of the welfare state have become even more glaring as more immigrants have moved to Spain to stay. As Gutiérrez Resa (2013) puts it, immigrants are putting Spanish social services and the Spanish welfare model itself to the test. 
So, the growing institutionalization of public policy on the integration of the immigrant population in Spain (Fernández Suárez 2018) has paralleled the management of the integration of the immigrant population in Spain by third-sector entities, in a story closely resembling that of development cooperation policies (Revilla Blanco 2002).

In this sense, it is especially important to throw light on the relationship between an NGDO's commitment to the realm of migration and development (or codevelopment) and the entity's survival and evolution, as we shall see later in section four. Also, the economic crisis marked a turning point in the work of many entities, as they dialed back the intensity of their criticism and demands and rebranded themselves as "agencies" managing official return programs or providing vocational training (Cebolla Boado, López Sala 2015).

In the case of Spain, the immigrant population has arrived in a space already occupied by an organized local civil society, thronging with busy political parties, labor unions, nonprofits of all kinds, NGDOs for international cooperation and even proimmigrant NGOs. Immigrants claim their right to play a role as agents in a field they have been the last to enter, and they face numerous obstacles to acknowledgement. In fact, though immigrants' associations to a fair extent run the same risks as the rest of the organizations in the third sector, their risks are accentuated due to their greater structural vulnerability and their weak incorporation into the receiving society. Some immigrants have found in the pre-existing fabric a way to participate in society, while others have tended to build their own structures in the form of immigrants' associations, although the vast majority of the immigrant population (like the vast majority of the autochthonous population) seems disinclined to engage in association life.

One interesting finding of our research is that a good many of the surveyed entities (252) were chartered in the 1990s and the first decade of the 2000s, coinciding with the rise of migration in Spain, migratory and refugee crises and the various government agencies' need to outsource services. It is also revealing that $6 \%$ of the surveyed organizations evolved from immigrants' associations into NGDOs and can now compete for certain kinds of subsidies and gain greater public recognition. This fact confirms the dynamism of immigrant association formation and the conversion of immigrant associations into NGDOs as a means of expanding the organization's possibilities of working in social action at the destination location and in development cooperation in countries of origin. So, immigration has injected greater diversity into Spanish civil society, in terms of individuals and in terms of collectives. Many immigrants participate in all kinds of different "domestic" associations (including social, cultural, festive and athletic associations), as volunteers, paid professionals or technicians, or as collectives, launching their own organizational structures (Lacomba, Aboussi 2017).

These new actors make the panorama so much richer in complexity that it is sometimes hard to distinguish clearly between domestic associations/NGDOs and immigrants' associations/NGDOs. NGDOs and other kinds of domestic social organizations have immigrants among their members, even in their leadership, and many 
immigrants' associations are not just for immigrants any more, but number autochthonous people in their ranks. Composite entities whose national flavor is hard to label have become more and more common.

NGDOs are a fundamental part of the third sector in Spain. At the time this article was written, 2,051 NGDOs were entered in the AECID's register. Since all the surveyed organizations are registered with $A E C I D$, obviously their main area of action is development cooperation. A large share (55\%), however, are involved in activities of a more local or national slant, such as awareness raising, development education and social action. There are also NGDOs that act as migration NGOs or pro-immigration NGOs by pressuring the state and its policies to defend human rights (political influence), NGDOs that focus on work to aid and support migrants and NGDOs that act directly to give migrants a voice.

The map of organizations in the field of migration and development has, then, become more complex, as shown in Figure 1. This growing organizational complexity ought to be reflected in a reclassification of the categories hitherto used. The considerable extant diversity should be reflected by taking account of each organization's makeup (NGDOs with a domestic base, composite NGDOs and NGDOs with a migrant base) and purpose (NGDOs oriented toward international development cooperation, NGDOs oriented toward domestic social action, domestic and international development NGDOs and pro-immigrant NGDOs focusing on defending immigrants' rights) and differentiating between what we call "immigration NGDOs" (which impact the field of migration but do not come from the migration field), "migrant NGDOs" (which have evolved from immigrants' associations, also termed "NGDOs with a migrant-led base") and immigrants' associations that remain unchanged.

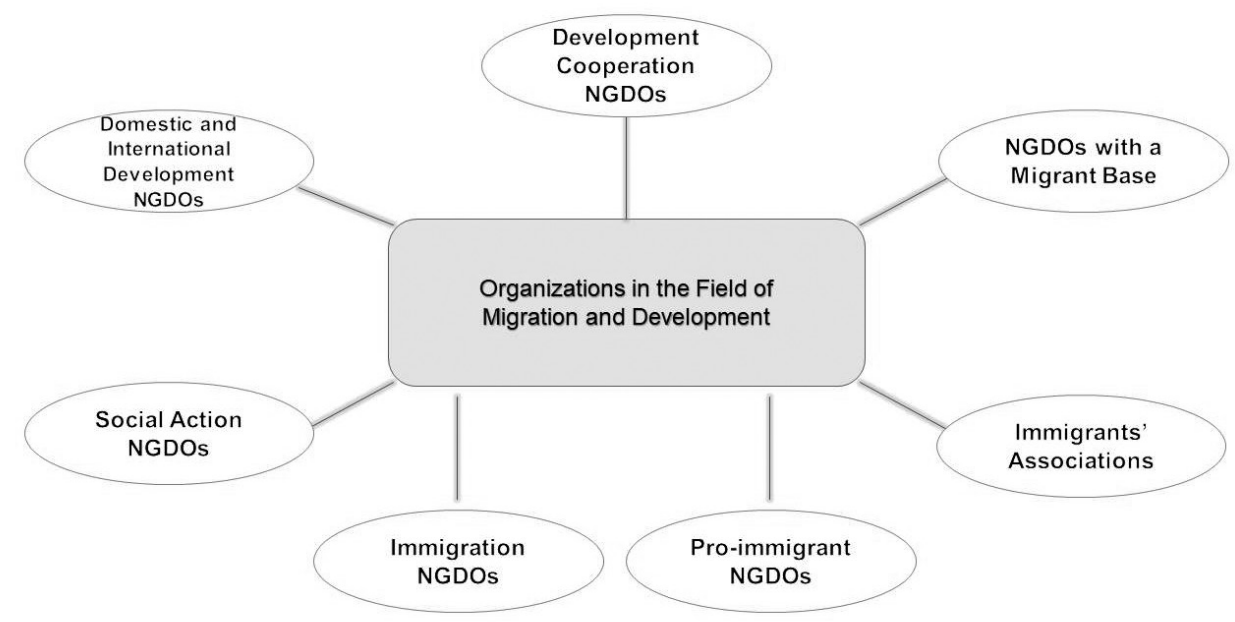

Figure 1: Map of Organizations in the Field of Migration and Development (source: prepared by the authors). 


\section{THE ROLE OF AND RELATIONSHIPS BETWEEN NGDOS AND IMMIGRANTS' ASSOCIATIONS}

Although some research has explored the role and functions of NGDOs and immigrants' associations, studies addressing the relationships between organizations in the field of development or in the field of immigration are far fewer. Studies analyzing the relationships between organizations from both fields are almost the exception. An added difficulty for work of that type is that, at least in Spain, there are many non-governmental organizations that work in both fields, so the line between international development cooperation on one side and social action with immigrants and the defense of immigrant rights on the other is blurred.

Immigrants' associations have performed an important function in the integration and participation of the migrant population over recent years. Immigrants' associations in Spain have roused the interest of researchers including Aparicio and Tornos (2010), Morell Blanch (2005) and Martín Pérez (2004). Though perhaps they have won less public recognition of their work than NGDOs. For example, the study done by Feldman et al. (2005) in Ireland underscores the role immigrants' organizations play in facilitating access to participation in civil society by sectors that find it harder to participate.

Likewise, immigrant associational initiatives can be understood as a strategy for reaching out to the receiving society and entering into contact with its various actors. The creation of associations in the receiving context may also arise as a response to needs shared by a specific collective, generally of a single nationality, who share common problems (Aboussi et al. 2013). This is what makes immigrants' associations fundamental actors for the construction of social learning in difficult areas: They can identify problems, voice the collective's demands and propose solutions (Brown, Timer 2006). Although migrant civil society organizations bear similarities to local civil society organizations, they differ in the way they address the wellbeing of migrant persons (Theodore, Martin 2007).

As for relationships between NGDOs and immigrants' associations, studies of the field of development cooperation tend to focus only on NGDOs, while studies tackling the field of immigrant organizations tend to skip over NGDOs and focus on the role of either pro-immigrant NGOs or immigrants' associations. There is very little research connecting the two types of organizations. Our research found that $36 \%$ of the NGDOs surveyed report having had relationships with migrants' associations. Most of these relationships, though, are described as informal occasional, informal continued or formal occasional relationships (confirmed by $53 \%$ of the answers, while $47 \%$ indicate formal continued relationships). This can be interpreted to mean that contacts and encounters are sought sporadically, on an as-needed basis. The realms where the surveyed NGDOs work most frequently with migrants' associations are awareness-raising activities, training for 
immigrants, interculturality and education for development. We take a particular interest in the realm of networking, as only 43 entities confirmed having engaged in relationships for that purpose.

Analyzing the possible factors behind relationships between NGDOs and immigrants' associations, Roca (2006) looked at NGDOs in Andalusia and reached the conclusion that what relations are established are usually competitive, not cooperative. Actually, the competition for resources and fields of action among NGDOs is not very different from the competition between NGDOs and immigrants' associations. On organizations in the migration field, Cullen's Irish study (2009) describes how pro-immigrant NGOs are criticized for having few immigrants among their executive leadership and for being reluctant to work with organizations led directly by migrants (Cullen 2009). For Cullen the obstacles to coalition-based mobilization include a political context in favor of restricting immigration, a reluctance among already-existing NGOs to work with the sector of emerging migrant-led NGOs and a cutthroat financing environment that hampers collaboration (Cullen 2009).

The study conducted by Feldman et al. (2005), also in Ireland, stresses the difficulties in the relationship terrain between what researchers call "majority society organizations" and "minority ethnic-led organizations," whose clashes Feldman believes are more closely linked to differences in organizational/administrative logic (each organization's organizational and management style) and relationships between organizations and the immigrant population (greater closeness/familiarity in the case of immigrants' organizations) than to any real competition for resources (Feldman et al. 2005).

In Spain many immigrants' associations have moved on from performing their original community function based on ethnic identification to taking action in the social realm, where they provide the whole immigrant population with services. This course of action can be a factor of greater competition (Many NGDOs too have moved on, as we have mentioned, from acting in the realm of development cooperation to acting in the realm of social action). The transformation process could be considered part of immigrants' associations' "natural" evolution as they incorporate themselves into the receiving society, and it could be considered as an indicator of integration, but it also forms part of the adoption of local approaches due to certain public policies (the accommodation referred to by Feldman et al. 2005), or as part of the strategies organizations use irrespective of institutional pressure (Arvidson 2018).

Looking at the effect of public policies, Landolt, Goldring and Bernhard (2009) explore how organizations of Latin-American migrants in Toronto have taken different forms, even though Canadian multicultural policy is the same for them all. Budgetary limits and the service provision model have acted differentially, though, giving privileges to the pan-ethnic organizations that render multiple services; this has worked to the detriment of ethno-specific organizations whose ability to engage in dialogue with the state is much weaker (Landolt, Goldring, Bernhard 2009). 
Richmond and Shields (2005) see the same trend. They show how the Canadian government's funding rationale has favored larger multi-service organizations that have more resources to begin with to devote to restructuring, administration and negotiation with fund providers, while grassroots or ethnic organizations have been forced to partner with the larger organizations (the multi-service organizations, which could be compared to Spain's NGDOs), cut back their services or go under (Richmond, Shields 2005).

In the case of Spain, in the first decade of the 21st century, co-development policies promoted some of these changes; we might call this phase one of codevelopment. Various public funding opportunities in the pre-crisis years largely focused on co-development as a line of cooperation. Later, despite the elimination of a substantial number of co-development policies, development and immigration entities have continued maintaining certain forms of collaboration, although in recent years the number of experiences has fallen considerably. Phase one, which happened before the Spanish crisis, worked to generate alliances among entities. Immigrants' associations gained in capability (they became stronger and started acting more as NGDOs' equals) and won seats in representative forums where they could promote changes in institutional agendas. Later, many associations - and NGDOs too - came out of the crisis weaker both structurally and in terms of their demands, and they have redirected their efforts toward covering more-basic needs and working to maintain a climate of peaceful coexistence while under the threat of collective instability.

Based on the evidence we have collected in our own research, we propose that there are six ways in which NGDOs interact with immigrants' associations:

1) Mimicking: Immigrants' associations adopt typical NGDO modes of action and thought, becoming NGDOs themselves.

2) Co-opting: NGDOs lure immigrant associations' leaders or mostprofessionalized members away and fold them into their own structures.

3) Subordination: Immigrants' associations act according to the demands of NGDOs.

4) Cooperation: NGDOs and immigrants' associations participate in a horizontal relationship in pursuit of common objectives.

5) Competition: NGDOs and immigrants' associations vie with one another at public funding opportunities.

6) Encapsulation: Immigrants' associations shut themselves away from NGDOs (and all other organizations in the receiving civil society) in order to maintain their own objectives or their own idiosyncrasy as ethnic/community associations. 


\section{RECOGNITION AND TRANSNATIONALIZATION}

While establishing contacts and creating institutional ties inside and outside Spain is fundamental for NGDOs if they want to receive public recognition and expand the scale of their work in international cooperation, this issue takes on a special dimension for immigrants' associations. Immigrants' associations are influenced by the characteristics of the civil society of receiving countries and by their own interactions with the state and other sectors of society. At the same time, they maintain relations with the society, organizations and state of their countries of origin. As a result, immigrants' associations are a fundamental actor in what has come to be called transnational civil society (Escobar 2010). In this interconnected space where the civil society of origin and the receiving civil society interact, immigrants' associations have a central quality that in some cases may be worked up into a source of political recognition.

Adding to their repertoire of ties with their counterparts in the cooperation sector and immigrants' associations, NGDOs too have been weaving a wide web of institutional relationships with other official and unofficial actors, in Spain and in the countries where they operate. Our research brings to light some highly significant data: $76 \%$ of the surveyed organizations report that they have relationships with other NGDOs; $48 \%$ connect with entities in developing countries; $43.7 \%$, with other social entities in Spain; $26.2 \%$, with European Union organizations, and $18.8 \%$, with other international organizations.

These institutional relationships are based as much on the needs inherent in the work itself as on a strategic approach, which involves finding allies and participating in realms where political influence is wielded and political decisions are made. NGDOs have joined national platforms like the Coordinator (and other umbrella organizations at the autonomous community level), supranational platforms like the European Confederation of Relief and Development NGOs (CONCORD) and networks whose participants also include immigrants' associations, in the attempt to gain a larger footprint in domestic institutional spaces like the Consejo de Cooperación Estatal (Development Cooperation Council) and to get a certain amount of recognition from the state agencies where they work (local bodies, official agencies and ministries) and from some international organizations that operate in the realm of cooperation (the European Union itself, regional development banks and the UN).

Immigrants' associations have also striven in their turn to become part of domestic networks and platforms with entities dealing with immigration and with development. Above all they have tried to extend their footprint to other forums with greater international clout through civil society initiatives (EUNOMAD, the European Network on Migrations and Development) or other, more-institutional initiatives (the United Nations' Global Forum on Migration and Development, which includes a long list of institutions but also has an increasingly large space for participation by organizations from civil society). For example, CODENAF (an association of Moroccan immigrants that is also registered as an NGDO) participates at the autonomous-community level 
in the Foros Provinciales de la Inmigración (Provincial Immigration Forums) of Sevilla, Almería, Málaga, Granada and Huelva, the Asociación Sevillana de ONGD (Seville Association of NGDOs), the Foro Andaluz de la Inmigración (Andalusian Forum on Immigration), the Coordinadora Andaluza de ONGD (Andalusian NGDO Coordinator), the Red Anti-Rumores (Anti-Rumor Network) and the Red Andaluza de Lucha contra la Pobreza y la Exclusión Social (Andalusian Network to Combat Poverty and Social Exclusion); at the nationwide level, it participates in the Foro para la Integración Social de los Inmigrantes (Forum for the Social Integration of Immigrants); and at the European level it participates in the Plateforme Euro-Marocaine Migration, Développement, Citoyenneté et Démocratie (Euro-Moroccan Platform on Migration, Development, Citizenship and Democracy).

Part of this growing participation can be chalked up to the effect of the framework of political opportunity generated by the institutionalization of development cooperation policies and immigration policies, especially the structure offered due to the design and implementation of specific policies on co-development ${ }^{2}$ (or migration and development) in some European countries, particularly countries like Spain, France and Italy. But it also has to do with the growing potential and agency capability of immigrants' associations themselves. They have mobilized to force their own presence into these policies, force others to recognize them in the framework of these policies and even drive policy design. Actually, as Moraes and Cutillas (2018) point out, the structural limitations on opportunities sometimes turn out to be better mobilizers than the framework of political opportunities. What is more, the framework of political opportunity is not the only factor in immigrants' associations' involvement in the field of international development and their subsequent transformation into NGDOs. Such outcomes can also be a response to the association's determination to show solidarity with its members' country or area of origin or a desire to combat those factors that caused the migration of the association's leaders, who look on themselves as a "sacrificed" generation and associate the association's migration projects with the duty to foster development in their home areas (Daum 2000; Gonin 2005).

The point is that a large number of immigrants' associations have expanded their effort to influence policy beyond the borders of their country of residence and gone transnational. The same has happened with immigrants from other nations in countries with a longer history of migration, like Mexicans in the United States (Bada 2014). Such is the case of associations like Rumiñahui, which was present in many of the forums where the Law on Human Mobility in Ecuador was discussed;

2 In Spain co-development has been defined as a mode of development cooperation based on promoting a positive link between migration and development, with the participation of institutional agents as well as NGDOs and immigrants' associations. Co-development has been integrated into official Spanish cooperation plans since 2005. However, we should draw attention to the fact that the concept has vanished from the latest plans for 2013-2016 and 2018-2021. 
likewise CODENAF, an association that makes itself heard in favor of greater democratization in Morocco through the Euro-Moroccan Platform on Migration, Development, Citizenship and Democracy; and AESCO, which is involved in the pacification of Colombian armed conflict through the Plataforma Colòmbia en Pau (Columbia at Peace Platform).

Immigrants' associations have many possibilities for transnationalization in their political impact. Some possibilities necessitate NGDO partners to provide greater capability, since NGDOs are usually better positioned politically. For example, small associations of immigrants from Senegal or Mali in Spain have implemented numerous local development projects in their countries of origin in collaboration with Spanish NGDOs. In many of these projects, the immigrants' associations have managed to overcome the obstacles posed by local authorities because of the mediation of the NGDOs, which have more muscle in terms of resources and political recognition in the framework of international cooperation. Furthermore, because of the transnational dimension of the action and organization of certain migrant-led NGDOs and immigrants' associations, such organizations are in some cases able to strengthen migrants' ability to bring pressure to bear on the political agendas of their country of origin and their receiving country. As a team they can break down the roadblocks on one side or the other, or both (Vogt 2006).

All these changes can be integrated into a synthetic model that reflects the role of and the relationships between organizations in the framework of the evolution of public policies, as shown below. This model illustrates how organizations reorient themselves to mirror the transformation of policies (from cooperation policy to co-development policy and more recently migration and development policy).

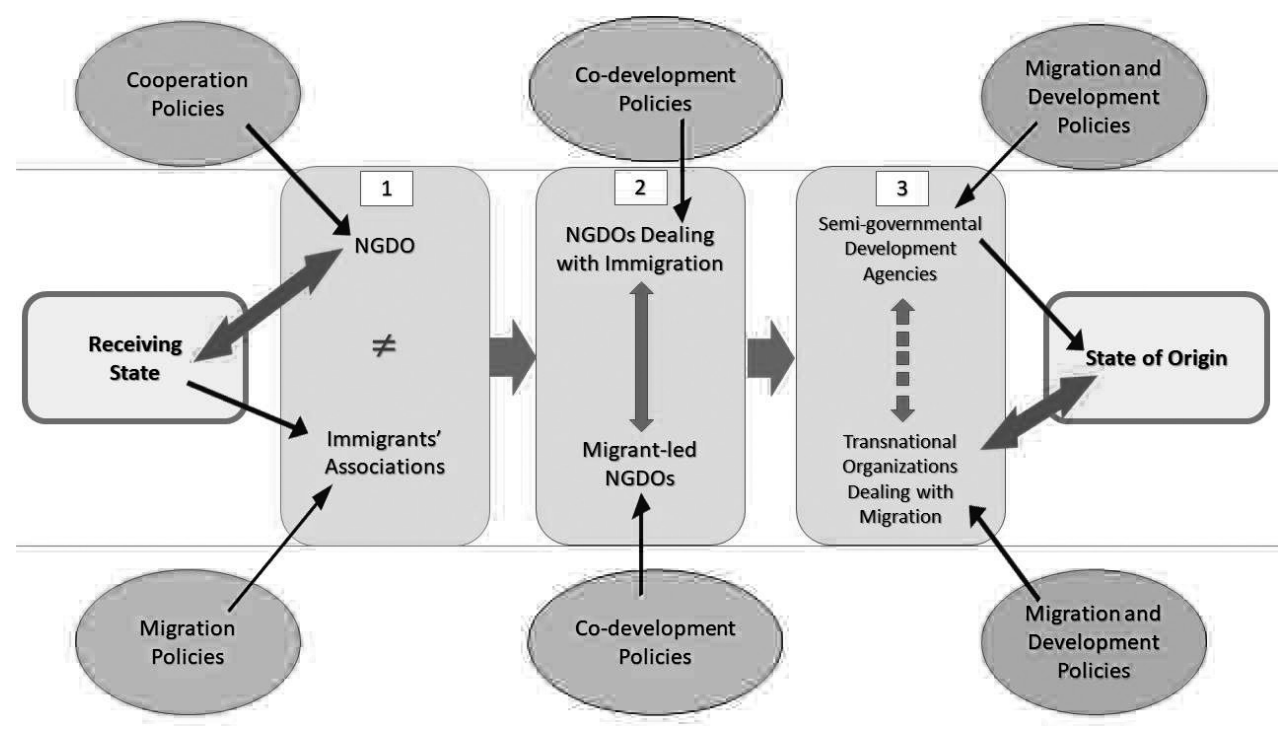

Figure 2: Synthetic Model (source: prepared by the authors). 


\section{CONCLUSIONS}

In this article we have tried to show some of the changes affecting the major organizations that work in the field of migration and development in Spain, NGDOs and immigrants' associations. Upon investigating the terrain, we have seen, first, how the range of organizations and their own transformations force us to use new categories for entities and broaden conventional classifications.

NGDOs themselves, which originated as organizations oriented specifically toward international development cooperation, have gradually taken on an increasingly pivotal role in the management of resources and programs targeting immigration. They have established new ties with other civil society organizations, like pro-immigrant NGOs and especially immigrants' associations. Immigrants' associations have in their turn succeeded at establishing new types of more-horizontal relationships with NGDOs. Some have even become NGDOs themselves. Vertical relationships, or an out-and-out lack of ties, are still the norm between NGDOs and immigrants' associations, however.

The influence of certain public policies, like the co-development policy espoused by Spanish government agencies and the diaspora policies of some states of migrant origin, have ended up affecting both the interrelationship between NGDOs and immigrants' associations and the transformation of organizations. In this framework of political opportunity, some immigrants' associations that are better positioned in their institutional relations have managed to consolidate themselves and set their own priorities. In the same framework, positive synergies have also been successfully generated between NGDOs and immigrants' associations, through drives by the former to strengthen the latter. Nevertheless, dependent and subordinate relationships still exist, in which smaller associations of immigrants depend on NGDOs for access to certain resources or the government ear (Richmond, Shields 2005).

Furthermore, when immigrants are in an NGDO, it gives them the opportunity to increase their social capital, because there they can expand their network of relations and contacts beyond the space of local society. Additionally, an entity that brings in immigrants can increase its intercultural competences according to Feldman et al. (2005), who maintain that immigrant membership has catalyzed an intercultural learning process in the sector of Irish migration organizations, generating fresh innovations and possibly new forms of social capital or intercultural capital.

Co-development as a line of cooperation was largely featured in various public funding opportunities in the pre-crisis years. At that time, it posed a window of political opportunity not only for NGDOs (as a fresh source of funds), but also for immigrants' associations (because it speeded up their transformation into NGDOs and enhanced their transnational dimension). It also forced them to establish alliances with other Spanish social entities, even though not all of them were ready for it. Nevertheless, co-development work has slowed down to a trickle, and some public institutions have even stopped financing it. In the new post-crisis stage, the policies that 
tried until not too long ago to promote development through migration have now been called into question. And let no one be deceived; today's policies have indeed gone back to framing development aid as a way of controlling migration, because they talk about "migration and development," not "co-development". The new stage also coincides with a larger degree of settlement and heterogeneity in immigration, plus organizations that are increasingly complex and hybridized, making it harder and more pointless to try and distinguish between immigrants' associations and NGDOs, between entities that work with immigrants and those that work with the local population, and between social action entities and development organizations. All these things are forcing us to question certain hitherto accepted categories and to rethink the role of organizations themselves in the framework of policy changes.

\section{REFERENCES}

Aboussi, Mourad, Espadas, María Ángeles, Raya Lozano, Enrique (2013). Associations of Immigrants in the third Sector in Andalucía: Governance and Networking Issues. Voluntas: International Journal of Voluntary and Nonprofit Organizations 24/2, 441-460.

Aparicio, Rosa, Tornos, Andrés (2010). Las asociaciones de inmigrantes en España: Una visión de conjunto. Madrid: Ministerio de Trabajo e Inmigración.

Arvidson, Malin (2018). Change and Tensions in Non-profit Organizations: Beyond the Isomorphism Trajectory. Voluntas: International Journal of Voluntary and Nonprofit Organizations 29/5, 898-910.

Bada, Xóchitl (2014). Mexican Hometown Associations in Chicagoacán: From Local to Transnational Civic Engagement. Chicago: Rutgers University Press.

Bloemraad, Irene (2005). The Limits of de Tocqueville: How Government Facilitates Organisational Capacity in Newcomer Communities. Journal of Ethnic and Migration Studies 31/5, 865-887.

Brown, L. David, Timmer, Vanessa (2006). Civil Society Actions as Catalysts for Transnational Social Learning. Voluntas 17/1, 1-16.

Cachón, Lorenzo, Laparra, Miguel (2009). Sistema migratorio, mercado de trabajo y regimen de bienestar: El Nuevo modelo del sur de Europa. Inmigración y políticas sociales (eds. Lorenzo Cachón, Miguel Laparra). Barcelona: Bellaterra, 19-50.

Cebolla Boado, Héctor, López Sala, Ana (2015). Transnational Latin American Immigrant Associations in Spain Suring the Economic Recession: A Top-down Model of Integration and Transnationalism at Stake? Immigrant Vulnerability and Resilience (eds. María Aysa Lastra, Lorenzo Cachón). Switzerland: Springer International Publishing, 163-180.

Cullen, Pauline (2009). Irish Pro-Migrant Nongovernmental Organizations and the Politics of Immigration. Voluntas: International Journal of Voluntary and Nonprofit Organizations 20/2, 99-128. 
Daum, Cristophe (2000). Typologie des Organisations de solidarité issues de l'immigration: Rapport pour la Commission Coopération-Codéveloppement. Paris: Ministère des Affaires étrangères.

Escobar, Cristina (2010). Exploring Transnational Civil Society: A Comparative Study of Colombian, Dominican and Mexican Immigrant Organizations in the USA. Journal of Civil Society 6/3, 205-235.

Feldman, Alice et. al. (2005). Diversity, Civil Society and Social Change in Ireland. Dublin: Migration \& Citizenship Research Initiative Geary Institute, University College Dublin.

Fernández Suárez, Belén (2018). La alteridad domesticada: La política de integración de inmigrantes en España: Actores y territorios. Barcelona: Editorial Bellaterra.

Fox, Jonathan (2005). Repensar lo rural ante la globalización: La sociedad civil migrante. Migración y Desarrollo 5, 35-58.

Fundación Lealtad (2015). Situación actual de las ONG en España. Madrid: Fundación Lealtad.

Garkisch, Michael, Heidingsfelder, Jens, Beckmann, Markus (2017). Third Sector Organizations and Migration: A Systematic Literature Review on the Contribution of Third Sector Organizations in View of Flight, Migration and Refugee Crises. Voluntas: International Journal of Voluntary and Nonprofit Organizations 28/5, 1839-1880.

Gonin, Patrick (2005). Jeux d'acteurs et enjeux territoriaux : Quelles migrations pour quel développement? L'exemple du bassin du fleuve Sénégal (république du Mali). Émigrés-Immigrés dans le développement local (eds. Mohammed Charef, Patrick Gonin). Agadir: ORMES/Sud Contact, 259-278.

Gutiérrez Resa, Antonio (2013). Los Servicios Sociales en España, puestos a prueba por las personas inmigrantes. Comunitania 5, 201-227.

Kendall, Jeremy, Almond, Stephen (1999). Reino Unido. La sociedad civil global. Las dimensiones del sector no lucrativo. Proyecto de estudio comparativo de la Universidad John Hopkins (ed. Lester Salamon). Bilbao: Fundación BBVA, 231-256.

Lacomba, Joan, Aboussi, Mourad (2017). La inmigración y su contribución a la sociedad civil española y el desarrollo. Tiempo de Paz 217, 106-118.

Landolt, Patricia, Goldring, Luin, Bernhard, Judith (2009). Las orgnanizaciones de migrantes latinoamericanos en Toronto: Entre la política de base y el imperativo de la etnización del Estado multicultural. Migración y participación política (eds. Ángeles Escrivá, Anastasia Bermúdez, Natalia Moraes). Madrid : CSIC, 203-234.

Martín Pérez, Alberto (2004). Las asociaciones de inmigrantes en el debate sobre las nuevas formas de participación política y de ciudadanía: Reflexiones sobre algunas experiencias en España. Migraciones 15, 113-143.

Moraes, Natalia, Cutillas, Isabel (2018). La estructura de oportunidad política transnacional y el giro relacional en el análisis de la participación política y el asociacionismo migrante. Papers 103/4, 605-624.

Morell Blanch, Antonio (2005). El papel de las asociaciones de inmigrantes en la sociedad de acogida: Cuestiones teóricas y evidencia empírica. Revista Migraciones 17, 111-142. 
Moreno, Francisco Javier, Bruquetas, María (2011). Inmigración y Estado de Bienestar en España. Barcelona: La Caixa.

Paré, Sylvie, Maloumby Baka, Ralph Christian (2015). The Role of Public - Third Sector Relationships in Solving Social Issues: the Case of One-Stop-Shop Service for the Promotion of Female Immigrant Entrepreneurship in Montreal. Entrepreneurial Business and Economics Review 3/3, 123-141.

Plataforma de ONG de Acción Social \& Plataforma del Tercer Sector (2015). El Tercer Sector de Acción Social en 2015: Impacto de la crisis. Madrid: Plataforma de ONG de Acción Social \& Plataforma del Tercer Sector.

Price Waterhouse Coopers (2018). Radiografía del Tercer Sector Social en España: Retos y oportunidades en un entorno cambiante. Madrid: Fundación PwC.

Renes Ayala, Víctor (2018). La sostenibilidad del tercer sector de acción social ante los cambios en el modelo de bienestar. Bienestar social y políticas públicas: Retos para pactar el futuro (ed. Germán Jaráiz Arroyo). Madrid: La Catarata, 280-297.

Rodríguez Cabrero, Gregorio (2015). Avances, limitaciones y retos del Tercer Sector de Acción Social en España. Revista Española del Tercer Sector 30, 75-97.

Revilla Blanco, Marisa (2002). Las ONG como mecanismos de participación política. Las ONG y la política (ed. Marisa Revilla Blanco). Madrid: Ediciones Istmo, 9-48.

Revilla Blanco, Marisa (2015). Las ONG en España. España 2015: Situación social (ed. Cristóbal Torres Albero). Madrid: Centro de Investigaciones Sociológicas, 1160-1173.

Richmond, Ted, Shields, John (2005). NGO-government Relations and Immigrant Services: Contradictions and challenges. Journal of International Migration and Integration 6, 513-526.

Roca Martínez, Beltrán (2006). Entre la competencia y la cooperación: La construcción de redes entre las Organizaciones No Gubernamentales de Desarrollo en Andalucía. REDES Revista Hispana para el Análisis de Redes Sociales 11, 1-25.

Ruiz Olabuénaga, José Ignacio et. al. (1999). España. La sociedad civil global. Las dimensiones del sector no lucrativo: Proyecto de estudio comparativo de la Universidad John Hopkins (ed. Lester Salamon). Bilbao: Fundación BBVA, 213-228.

Saglie, Jo, Sivesind, Karl Henrik (2018). Civil Society Institutions or Semi-public Agencies? State Regulation of Parties and Voluntary Organizations in Norway. Journal of Civil Society 14/4, 292-310.

Salamon, Lester (1994). The Rise of the Nonprofit Sector. Foreign Affairs 73/4, 109-122.

Salamon, Lester (2003). The Resilient Sector: The Future of Nonprofit America. Washington: Brookings Institution Press.

Serrano Oñate, Maite (2019). Treinta años de la cooperación española: El papel de la sociedad civil. Revista española de desarrollo y cooperación 44, 57-64.

Theodore, Nik, Martin, Nina (2007). Migrant Civil Society: New Voices in the Struggle Over Community Development. Journal of Urban Affairs 29/3, 269-287.

Vogt, Gabriele (2006). Facing the Challenge of Immigration? The State, Civil Society and Structures of Interdependence. Working Papers of the German Institute for Japanese Studies 06/5, 1-41. 


\section{POVZETEK}

\section{MIGRACIJSKE IN RAZVOJNE ORGANIZACIJE: DIVERZIFIKACIJA CIVILNE DRUŽBE IN JAVNIH POLITIK V ŠPANIJI Joan LACOMBA, Mourad ABOUSSI}

Članek, ki temelji na ugotovitvah dveh v enaki meri kvantitativnih in kvalitativnih raziskovalnih projektov, izvedenih v Španiji, obravnava spremembe in nove oblike odnosov med glavnimi protagonisti na področju migracij in razvoja. Ena najzanimivejših sprememb v zadnjih dveh desetletjih na področju tretjega sektorja v Španiji je bil, skupaj z reakomodacijo drugih akterjev, ki niso veliko starejši od prišlekov (NVRO-ji), vstop novih akterjev na prizorišče civilne družbe (priseljenska združenja). Njihova skupna prizadevanja in prispevki za ustvarjanje trdnejše, bolj raznolike civilne družbe so pogosto neznani.

Članek začenja hipoteza, da se tako spremembe, ki vplivajo na odnose med državo in civilno družbo, kot tudi vplivi določenih javnih politik razločno zrcalijo $v$ preurejanju tretjega sektorja. Zato sta avtorja v članku na različnih mestih prikazala, kako se razvojne in priseljenske organizacije vključujejo $v$ španski tretji sektor, pri čemer sta upoštevala tako kompleksnost tega sektorja kot tudi raznolikost vseh udeležencev. Analizirata tudi pomen in težavno povezovanje med NVRO-ji in priseljenskimi združenji, pri čemer se osredotočata na učinek javnih sorazvojnih politik na spreminjanje odnosov med organizacijami v smislu večje organizacijske prepoznavnosti in transnacionalizacije. Njune ugotovitve potrjujejo pomembnost političnih priložnosti, ki jih skupaj z oblikovanjem in implementacijo specifičnih sorazvojnih politik poraja institucionalizacija razvojnih kooperativnih politik in priseljenskih politik. $V$ tem smislu so nevladne razvojne organizacije, ki so še zlasti usmerjene $k$ mednarodnemu razvojnemu sodelovanju, sčasoma dobile vodilno vlogo v upravljanju sredstev in programov, namenjenih priseljencem, hkrati pa so stkale nove vezi z drugimi civilnodružbenimi organizacijami, kot so proimigrantske nevladne organizacije in še zlasti priseljenska združenja. 